\title{
Medievalista
}

Online

$24 \mid 2018$

Número 24

\section{Fernão Lopes, Crónica de Dom João I. Primeira Parte}

\author{
Isabel Barros Dias
}

\section{OpenEdition}

\section{Journals}

Edição electrónica

URL: http://journals.openedition.org/medievalista/1707

DOI: 10.4000/medievalista. 1707

ISSN: 1646-740X

\section{Editora}

Instituto de Estudos Medievais - FCSH-UNL

\section{Refêrencia eletrónica}

Isabel Barros Dias, «Fernão Lopes, Crónica de Dom João I. Primeira Parte », Medievalista [Online], 24 |

2018, posto online no dia 16 março 2019, consultado o 10 dezembro 2020. URL : http://

journals.openedition.org/medievalista/1707 ; DOI : https://doi.org/10.4000/medievalista.1707

Este documento foi criado de forma automática no dia 10 dezembro 2020

\section{(c) (i) (9)}

Mediavalista está licenciado com uma Licença Creative Commons - Atribuição-NãoComercial 4.0 Internacional. 


\title{
Fernão Lopes, Crónica de Dom João I. Primeira Parte
}

\author{
Isabel Barros Dias
}

\section{REFERÊNCIA}

LOPES, Fernão - Crónica de Dom João I. Primeira Parte. Edição crítica e notas de Teresa Amado, com a colaboração de Ariadne Nunes, Carlota Pimenta e Mário Costa, Introdução de Cristina Sobral. Lisboa: Imprensa Nacional e Centro de Estudos Comparatistas, 2017 (390 pp)

\section{NOTA DO EDITOR}

Data recepção do artigo / Received for publication: 30-04-2018

Constitui um acontecimento maior para os estudos de História Medieval e de Literatura Medieval a há muito esperada edição da I Parte da Crónica de D. João I. A fortuna editorial mais recente deste texto contrasta com o sucesso que teve no passado. Tal como referido na Introdução à presente edição, “os autógrafos não sobreviveram. Tão pouco foram preservados os apógrafos contemporâneos do autor. Os manuscritos mais antigos são manuelinos" (Intr., p. 7), porém, o grupo responsável pela nova edição identificou quarenta e três testemunhos da I Parte da Crónica de D. João I, "dos quais vinte e quatro são datáveis desde o final do século XV até ao final do século XVI” (ibidem, p. 8). Em flagrante oposição, antes da presente edição, para além de algumas publicações de excertos e de versões parciais, Anselmo Braamcamp Freire levou a cabo a transcrição de um manuscrito, em 1915. Esta edição foi, posteriormente, objeto de uma edição facsimilada da IN-CM, prefaciada por Lindley Cintra (em 1973), e reimpressa pela ed. Civilização em 1945, 1990, 1991 e 1994, livros desde há muito esgotados e, mesmo em alfarrabistas, de difícil acesso. Dado este panorama, há muito que se sentia a falta de uma nova edição da obra de Fernão Lopes, baseada em critérios atualizados e fiáveis, 
que colocasse à disposição do público a obra daquele que é considerado como um dos mais inspirados e originais historiadores europeus medievais.

2 O manuscrito escolhido para texto-base da presente edição foi o mesmo que Braamcamp Freire editara, o exemplar da Torre do Tombo, Casa Forte, Crónicas 8 (olim cod. 352). Trata-se de um códice de boa qualidade, elaborado no quadro da chamada "Leitura Nova" manuelina e que, como explicado na introdução, "confrontado com outros manuscritos quinhentistas, raramente revelou defeitos que o desqualificassem." (ibidem, p. 11). Apesar de valorizar o mesmo exemplar, a edição agora dada à estampa apresenta-se, não como uma transcrição do melhor exemplar, como a anterior edição, de índole bédierista, mas tendencialmente neolachmaniana. Tendo a equipa editorial transcrito e colacionado dezanove manuscritos quinhentistas, surpreende o reduzido número de notas existente na presente edição crítica da I Parte da Crónica de D. João I, o que indica que a transmissão desta obra, que terá sido redigida entre 1441 e 1450, foi de uma enorme estabilidade. Não sendo muito comum, este facto demonstra o cuidado com que terão sido realizadas as cópias e o respeito que, desde cedo, terá havido pela figura autoral de Fernão Lopes, não só enquanto narrador do passado, mas também como um dos primeiros grandes mestres da narrativa literária portuguesa.

3 A introdução à edição crítica, da autoria de Cristina Sobral, para além de contextualizar o trabalho realizado, refere ainda e justifica as opções tomadas pela equipa editorial e recorda as vicissitudes deste processo de edição, sem esquecer a literatura crítica existente. Com efeito, o estudo da obra de Fernão Lopes foi realizado, sobretudo, por Teresa Amado, que também estabeleceu as bases para a presente edição, nomeadamente, normas de transcrição e critérios de edição. $O$ resultado consiste num texto que, sem perder a cor epocal, nem transigir na fiabilidade, permite a vulgarização da Crónica, uma vez que, para além de modernizar algumas grafias e de conter pouca sinalética editorial, apresenta uma mancha gráfica atraente, cuja leitura é facilmente acessível a um público heterogéneo, desde que com suficiente flexibilidade para apreciar uma prosa que, apesar de relativamente distante da atual, não pode ser considerada opaca.

O falecimento da grande impulsionadora dos projetos de edição e de tradução para o inglês da Crónica de D. João I, Teresa Amado, em 2013, poderia ter feito soçobrar as empresas. Porém, felizmente, as equipas destes dois projetos têm levado por diante o trabalho anteriormente encetado, estando por isso de parabéns. Mas, à imagem da historiografia que, enquanto o tempo fluir, não pode dar por encerrada a sua missão, também a tarefa encetada por esta edição crítica não está terminada. A importância que a obra de Fernão Lopes tem para a História e para a Literatura portuguesas deve constituir um incentivo para que a equipa editorial prossiga com o seu trabalho por forma a que, em breve, a II Parte da Crónica de D. João I se torne tão acessível ao público como neste momento está a sua I Parte. 


\section{AUTORES}

\section{ISABEL BARROS DIAS}

Universidade Aberta, Departamento de Humanidades

Universidade Nova de Lisboa, Faculdade de Ciências Sociais e Humanas, Instituto de Estudos de Literatura e Tradição; Instituto de Estudos Medievais, 1269-001, Lisboa, Portugal

isabel.dias@uab.pt 